\title{
Studi Komparatif Mediasi Antara Peraturan Mahkamah Agung (PERMA) Nomor I Tahun 2008 Dan Peraturan Mahkamah Agung (PERMA) Nomor I Tahun 2016
}

\author{
Evalina Alissa*, Yeni Erwita** \\ evalinadasril@yahoo.co.id \\ yennierwita58@gmail.com
}

\begin{abstract}
ABSTRAK
Mediasi sebagai instrumen penyelesaian sengketa berdasarkan ketentuan Pasal 130 HIR dan Pasal 154 Rbg yang mewajibkan hakim untukterlebih dahulu mendamaikan para pihak yang berperkara sebelum perkaranya diperiksa. Diundangkannya PERMA No. I Tahun 2008 dan diperbaharui dengan PERMA No.ITahun 2016 yang memberikan panduan tentang penjelasan prosedur mediasi bagi para pihak untuk menyatakan perdamaian. Objek masalah hukum dalam penelitian ini adalah menganalisis perbandingan substansi dari dua Peraturan Mahkamah Agung, dan menganalisis efektivitas mediasi sebagai solusi untuk mengurangi akumulasi kasus sehingga mewujudkan proses peradilan yang cepat dan murah. Pendekatan penelitian yang dilakukan adalah statuta dan pendekatan konseptual terhadap materi hukum yang telah dikumpulkan melalui penelitian kepustakaan. Hasil penelitian menunjukkan bahwa ada beberapa pengaturan tentang mediasi, yang telah mengalami perubahan dalam Peraturan Mahkamah Agung Nomor I Tahun 2016 adalah: (1) kewajiban untuk memberikan formulir penjelasan hakim ketua majelis tentang mediasi dan formulir pernyataan para pihak tentang penjelasan mediasi yang wajib ditanda tangani para pihak, (2)mempersingkat waktu mediasi, kewajiban para pihak untuk secara langsung menghadiri pertemuan mediasi, (3) adanya niat baik dalam proses mediasi serta konsekuensi hukum jika niat baik ini dilanggar. Implementasi mediasi belum dapat menjadi sarana yang efektif untuk mengurangi akumulasi kasus perdata karena masih banyak kendala, termasuk rendahnya tingkat pemahaman dan kesadaran masyarakat tentang fungsi mediasi. Oleh karena itu, peran aktif hakim yang ditunjuk sebagai mediator untuk memberikan pemahaman dan pengetahuan yang benar tentang manfaat dan fungsi mediasi dalam sistem hukum perdata di Indonesia sehingga peradilan yang cepat dan murah dapat diwujudkan.
\end{abstract}

Kata kunci: Mediasi, Peraturan Mahkamah Agung, Sengketa Perdata

\section{PENDAHULUAN}

Artikel ini membahas tentang Studi Komparatif Mediasi Berdasarkan Peraturan Mahkamah Agung (PERMA) No.1 Tahun 2008 dengan Peraturan Mahkamah Agung (PERMA) No.1 Tahun 2016.Perdamaian dalam KUH Perdata diatur dalam Pasal $1851^{1}$, yang kemudian diatur lebih lanjut dalam Pasal 130 HIR dan Pasal 154 RBG yang menghendaki penyelesaian suatu sengketa melalui cara damai. Bunyi Pasal 130 HIR Ayat (1) yaitu : “ Jika pada hari yang ditentukan itu kedua pihak datang, maka Pengadilan Negeri dengan pertolongan ketua mencoba akan memperdamaikan mereka." Ayat (2) yaitu : Jika perdamaian yang demikian itu dapat dicapai, maka pada waktu bersidang, diperbuat sebuah surat (akta) tentang itu, dalam mana kedua belah pihak dihukum akan menaati perjanjian yang diperbuat itu, surat mana akan berkekuatan dan akan dijalankan sebagai putusan yang biasa." 2

Pasal 130 HIR dan Pasal 154 RBG, menghendaki penyelesaian suatu perkara perdata dengan melalui perdamaian, dari pada proses perkara melalui putusan biasa. Lebih menghendaki penerapan konsep win-win solution yaitu sama-sama menang, dari pada penerapan winning or losing, yaitu menang atau kalah. Bentuk penyelesaian yang digariskan Pasal 130 HIR ini lebih mirip merupakan kombinasi antara sistem mediasi atau konsiliasi. ${ }^{3}$

Para pihak yang menyelesaikan sendiri terlebih dahulu kesepakatan untuk damai tanpa campur tangan hakim, kemudian kesepakatan perdamaian itu dimintakan kepada hakim untuk 
dituangkan dalam bentuk akta perdamaian. Berati perdamaian yang disepakati para pihak yang berperkara itu hasil usaha para pihak, intervensi dan peran hakim sangat kecil, berupa pembuatan akta perdamaian yang dijatuhkan, sebagai putusan pengadilan yang berisi amar menghukum para pihak agar mentaati mematuhi isi perdamaian.

Pada prinsipnya upaya hakim untuk mendamaikan para pihak dalam perkara perdata bersifat imperatif. Hakim wajib berupaya mendamaikan para pihak yang berperkara. Hal ini dapat ditarik dari ketentuan Pasal 131 ayat (1) HIR, yang menyatakan : Jika hakim tidak dapat mendamaikan para pihak,maka hal itu mesti disebut dalam berita acara sidang.Jadi menurut pasal ini, kalau hakim tidak berhasil mendamaikan, maka ketidakberhasilan itu mesti ditegaskan dalam berita acara sidang. Kelalaian dalam menyebutkan hal itu dalam berita acara sidang, mengakibatkan pemeriksaan perkara : - mengandung cacat formil, dan berakibat pemeriksaan batal demi hukum.

Namun demikian, meskipun tahap proses mendamaikan itu bersifat imperatif, akan tetapi undang-undang sendiri tidak ada mengatur tentang ancaman hukumannya atas pelanggaran itu. Apabila pembuat undang-undang berpendapat kewajiban mendamaikan itu sangat penting (prinsipil) bobotnya, maka tentu akan diatur ancaman hukuman atas pelanggarannya. Dengan kata lain hakim yang mengabaikan atau melalaikan tahap proses perdamaian, maupun berita acara yang tidak memuat penjelasan tentang tidak berhasilnya upaya mendamaikan para pihak yang berperkara, dianggap pelanggaran tata tertib beracara biasa, yang tidak punya akibat yang menyatakan pemeriksaan tidak sah ataupun menyatakan batal demi hukum.

Kenyataan dalam praktek di pengadilan, masih sedikit perkara perdata yang diselesaikan dan diputus secara perdamaian melalui mediasi, hasilnya terdapat kegagalan, artinya dalam pelaksanaan mediasi banyak yang menyatakan bahwa ketika seseorang telah mengajukan gugatan ke pengadilan yang ada pihak lawanya, maka itu sudah merupakan keputusan akhir dan tidak ada titik temu dalam kasus mereka, maka proses pengadilanlah yang mereka lakukan. Produk yang dihasilkan oleh peradilan dalam menyelesaikan perkara yang diajukan kepadanya, berupa keputusan konvensional, keputusan yang menghasilkan menang atau kalah (winning or losing).Kritik pada lembaga peradilan kenapa masihsedikit dijumpai penyelesaian perkara berdasarkan konsep sama-sama menang (win-win solution). Berdasarkan fakta ini, kesungguhan, kemampuan, dan dedikasi hakim untuk mendamaikan boleh dikatakan sangat mandul. Tidak berperannya landasan hukum menyelesaikan perkara melalui perdamaian. Ada yang berpendapat, kemandulan itu bukan semat-mata disebabkan faktor kurangnya kemampuan, kecakapan dan dedikasi hakim, tetapi lebih didominasi motivasi dan peran advokat atau kuasa hukum. Mereka lebih cenderung mengarahkan proses letigasi berjalan terus, mulai dari peradilan tingkat pertama sampai peninjauan kembali, demi mengejar professional fee yang besar dan berlanjut.Akibatnya, keberadaan Pasal 130 HIR dan Pasal 154 RBG dalam hukum acara, tidak lebih dari hiasan belaka atau rumusan mati. ${ }^{4}$

Mahkamah Agung ( MA ) sebagai badan peradilan yang tertinggi di Indonesia mensinyalir adanya gejala perilaku hakim yang tidak bersungguh-sungguh dalam memberdayakan Pasal 130 HIR untuk mendamaikan para pihak yang bersengketa. Sikap dan perilaku hakim pada umumnya dalam menerapkan Pasal 130 HIR, hanyalah bersifat formalitas saja, hakim bersifat pasif, bukan karena panggilan hati, dedikasi dan seruan moral, sesuai dengan ungkapan yang mengatakan: keadilan yang hakiki diperoleh pihak yang bersengketa melalui perdamaian. ${ }^{5}$

Berdasarkan hal tersebut MA merasa terpanggil untuk lebih memberdayakan para hakim dalam menyelesaikan perkara dengan perdamaian yang telah digariskan dalam Pasal $130 \mathrm{HIR}$, melalui mekanisme integrasi mediasi dalam sistem peradilan. Landasan formil mengenai mediasi dalam sistem peradilan ini pada dasarnya, tetap bertitik tolak pada ketentuan Pasal 130 HIR, Pasal 154 RBG. Namun untuk lebih memberdayakan dan 
mengefektifkannya, MA memodefikasikannya kearah yang lebih bersifat memaksa ( compulsory) atau wajib (mandarory). ${ }^{6}$

Mahkamah Agung sejak tahun 2002, telah melakukan upaya untuk mengurangi penumpukan perkara di pengadilan, dengan mengeluarkan SEMA dan PERMA tentang Lembaga Damai dan Mediasi.Mediasi semula diatur dalam SEMA No. 1 Tahun 2002, yang diterbitkan pada tanggal 30 Januari 2002, yang berjudul " Pemberdayaan Pengadilan Tingkat Pertama Menerapkan Lembaga Damai ( Eks Pasal 130 ). Pada tanggal 11 September 2003, MA mengeluarkan PERMA No. 2 Tahun 2003, sebagai pengganti dari SEMA No. 1 Tahun 2002. PERMA No. 2 Tahun 2003 berjudul : "Prosedur Mediasi di Pengadilan". Pada tahun 2008, MA mengeluarkan PERMA No. 1 Tahun 2008 dengan judul : "Prosedur Mediasi", yang merupakan revisi dari PERMA No. 2 Tahun 2003. Kemudian PERMA No. 1 Tahun 2008 direvisi kembali oleh MA, karena dianggap kurang sempurna. dengan keluarnya PERMA No. 1 Tahun 2016 dengan judul : "Prosedur Mediasi". Dengan diterbitkannya PERMA No. 1 Tahun 2016, diharapkan dapat menjawab kelemahan-kelemahan dari PERMA yang lalu. Mediasi efektif karena prosesnya lebih cepat dan murah, serta memberikan akses kepada para pihak untuk memperoleh keadilan. Keberhasilan mediasi sebagai salah satu alternatif penyelesaian sengketa di Pengadilan sangat dibutuhkan oleh masyarakat pencari keadilan, serta untuk mengurangi penumpukan perkara.

Kebijakan MA mewajibkan proses Mediasi sebelum perkara diputus, ada 2 (dua) alasan yaitu : Pertama, MA telah menghadapi akumulasi kasus, masalah penumpukan perkara yang berkelanjutan. Keadaan ini telah menyedot sumber daya dan menyebabkan cita-cita mewujudkan peradilan yang cepat danmurah tidak dapat diwujudkan. Kedua, pengintegrasian mediasi kedalam proses peradilan dapat memberikan akses yang lebih luas kepada masyarakat untuk menemukan penyelesaian yang memuaskan dan adil menurut para pihak sendiri. ${ }^{7}$

Berdasarkan uraian latar belakang tersebut, maka rumusan masalah yang dibahas adalah : apa sajakah kelebihan dan kekurangan dari PERMA No. 1 Tahun 2008 dengan PERMA No. 1 Tahun 2016 dan apakah dengan dikeluarkannya PERMA ini dapat mengurangi penumpukan perkara dan tercipta peradilan yang cepat dan murah di Pengadilan.

Adapun metode dalam penelitian ini, menggunakan metode penelitian yuridis normatif. ${ }^{8}$ Pendekatan penelitiannya adalah pendekatan statuta dan pendekatan konseptual, terhadap materi hukum yang telah dikumpulkan melalui penelitian kepustakaan.

\section{PENGERTIAN MEDIASI}

Mediasi merupakan adopsi dari bahasa latin mediare yang berarti berada ditengah. ${ }^{9}$ Pengertian ini lebih mengarah kepada fungsi dan peranan mediator yakni sebagai penengah antara dua orang atau lebih yang salingbersengketa, oleh sebab itu, mediator harus mampu menjaga independensiserta menjaga keberpihakkan kepada salah satu pihak agar menumbuhkankepercayaan antara para pihak yang bersengketa.Rachmadi Usman mendefinisikan kata mediasi berasal dari bahasa Inggris“mediation" yang artinya pemecahan masalah dimana pihak luar yang tidak memihak (impartial) dan netral bekerja dengan pihak yang bersengketa untuk membantu mereka memperoleh kesepakatan perjanjian dengan memuaskan. ${ }^{10}$

Soesilo Prajogo dalam Kamus Hukum Internasional dan Indonesiamenjelaskan bahwa mediasi adalah proses penyelesaian sengketa secaradamai yang melibatkan bantuan pihak ketiga untuk memberikan solusi yangdapat diterima pihak-pihak yang bersengketa. Keberhasilan proses mediasibiasanya lebih banyak ditentukan oleh kemampuan berdiplomasi, kecakapandalam memberikan usulan-usulan yang bersifat tidak memihak, kualitas sertanetralitas pihak yang diminta untuk menjadi penengah. ${ }^{11}$ Pengertian mediasi juga dapat dijumpai dalam Pasal 1 butir 6 PERMA RI No. 2 Tahun 2003 yang menyatakan bahwa 
mediasiadalah penyelesaian sengketa melalui proses perundingan para pihak dengan dibantu oleh mediator.

PERMA No. 1 Tahun 2008 tentang Prosedur Mediasi di Pengadilan, pada Pasal 1 butir 7 disebutkan bahwa mediasi adalah cara penyelesaian sengketa melalui proses perundingan untuk memperoleh kesepakatan para pihak dengan dibantu oleh mediator.Dalam PERMA No 1 tahun 2016, bahwa yang dimaksud denganmediasi adalah cara penyelesaian sengketa melalui proses perundinganuntukmemperoleh kesepakatan para pihak dengan dibantu mediator.

Landasan formil mengenai mediasi dalam sistem peradilan ini pada dasarnya, tetap bertitik tolak pada ketentuan Pasal 130 HIR, Pasal 154 RBG. Namun untuk lebih memberdayakan dan mengefektifkannya, MA memodefikasikannya kearah yang lebih bersifat memaksa ( compulsory) atau wajib ( mandarory). ${ }^{12}$ Mediasi semula diatur dalam SEMA No. 1 Tahun 2002, yang berjudul " Pemberdayaan Pengadilan Tingkat Pertama Menerapkan Lembaga Damai ( Eks Pasal 130 ). Pada tanggal 11 September 2003, MA mengeluarkan PERMA No. 2 Tahun 2003. PERMA No. 2 Tahun 2003 berjudul : "Prosedur Mediasi di Pengadilan”. Pada tahun 2008, MA mengeluarkan PERMA No. 1 Tahun 2008 dengan judul : "Prosedur Mediasi" , yang merupakan revisi dari PERMA No. 2 Tahun 2003. Kemudian kembali MA mengluarkan PERMA No. 1 Tahun 2016 dengan judul : "Prosedur Mediasi", untuk merevisi PERMA No.1 Tahun 2008.

Dengan menyelesaikan perkaraa secara mediasi sekurang-kurangnya ada tujuh (7) keuntungan yang diperoleh, yaitu :

a. Untuk mengurangi kemacetan dan penumpukan perkara (court congestion)dilembaga peradilan. Banyaknya kasus yang diajukan ke pengadilan menyebabkan proses pengadilan sering kali berkepanjangan dan memakan biaya yang tinggi serta memberikan hasil yang kurang memuaskan.

b. Untuk meningkatkan keterlibatan masyarakat atau memberdayakan pihak-pihak yang bersengketa dalam proses penyelesaian sengketa.

c. Untuk memperlancar jalur keadilan (acces to justice) di masyarakat.

d. Untuk memberikan kesempatan bagi tercapainya penyelesaian sengketa yang menghasilkan keputusan yang dapat diterima oleh semua pihak (win-win solution)

e. Penyelesaian sengketa lebih cepat dan murah.

f. Bersifat tertutup / rahasia (confidential).

g. Lebih tinggi tingkat kemungkinan untuk melaksanakan kesepakatan, sehingga hubungan pihak-pihak yang bersengketa dimasa depan masih dimungkinkan terjalin. ${ }^{13}$

\section{PERBANDINGAN MEDIASI MENURUT PERMA NO. 1 TAHUN 2008 DENGAN PERMA NO. 1 TAHUN 2016.}

Pada tahun 2008, PERMA No. 2 Tahun 2003 diganti dengan PERMA No. 1 Tahun 2008. Dalam bagian menimbang dari PERMA ini disebutkan " bahwa setelah dilakukan evaluasi terhadap pelaksanaan prosedure mediasi di Pengadilan berdasarkan PERMA No. 2 Tahun 2003, ternyata ditemukan beberapa permasalahan yang bersumber dari PERMA tersebut sehingga PERMA No. 2 Tahun 2003 perlu direvisi dengan maksud untuk lebih mendayagunakan mediasi yang terkait dengan proses berperkara di Pengadilan".

Dalam PERMA No. 1 Tahun 2008, sifat wajib mediasi dalam proses berperkara di Pengadilan lebih dipertegas lagi, bisa dilihat dalam pasal yang menyatakan bahwa tidak ditempuhnya proses mediasi berdasarkan PERMA, merupakan pelanggaran terhadap ketentuan pasal $130 \mathrm{HIR} / 154 \mathrm{RBg}$ yang menyatakan putusan batal demi hukum ( Pasal 2 ayat(3)). ${ }^{14}$ Hakim dalam pertimbangan putusan perkara wajib menyebutkan bahwa perkara yang bersangkutan telah diupayakan perdamaian melalui mediasi dengan menyebutkan nama mediator untuk perkara tersebut.( Pasal 2 ayat (4)). ${ }^{15}$ 
Mahkamah Agung Republik Indonesia kemudian memperbaharui lagi PERMA dengan mengeluarkan kembali PERMA No. 1 Tahun 2016, setelah enam (6) tahun berlakunya PERMA No.1 Tahun 2008.

Ada perubahan ketentuan prosedur mediasi dalam PERMA No.1 Tahun 2008 dengan PERMA No.1 Tahun 2016 yaitu :

1. Jumlah Pasal dalam PERMA No.1 Tahun 2008 ada dua puluh tujuh pasal (27), sedangkan pasal dalam PERMA No.1 Tahun 2016 ada tiga puluh sembilan (39) pasal.

2. kewajiban untuk memberikan formulir, penjelasan hakim ketua majelis tentang mediasi dan formulir pernyataan para pihak tentang penjelasan mediasi yang wajib ditanda tangani para pihak. ${ }^{16}$

3. Jangka waktu pelaksanaan mediasi, dalam PERMA No.1 Tahun 2008 proses mediasi berlangsung paling lama 40 hari kerja sejak memilih mediator, atas kesepakatan para pihak jangka waktu mediasi dapat diperpanjang paling lama 14 hari kerja, sejak berakhirnya masa 40 hari (Pasal 13 ayat (3 dan 4). Dalam PERMA No. 1 Tahun 2016, proses mediasi berlangsung paling lama 30 hari kerja sejak memilih mediator, atas keepakatan para pihak, jangka waktu mediasi dapat diperpanjang paling lama 30 hari kerja (Pasal 24).

4. Kewajiban melaksanakan mediasi dengan itikad yang baik. Dalam PERMA No.1 Tahun 2008, terhadap penggugat yang tidak beritikad baik dalam melaksanakan mediasi tidak ada akibat hukumnya terhadap gugatannya. Dalam PERMA No.1 Tahun 2016, pelaksanaan mediasi dengan adanya para pihak yang tidak beritikad baik, mempunyai akibat hukum terhadap proses pemeriksaan perkara. Dapat dilihat dari aspek para pihak yang tidak beritikad baik yaitu : bagi penggugat yang beritikad tidak baik, akibat hukumnya gugatannya dinyatakan tidak diterima (NO), dan penggugat dikenai kewajiban membayar biaya mediasi. Bagi tergugat yang beritikad tidak baik akibat hukumnya, dikenai biaya mediasi(Pasal 7)

PERMA No.1 Tahun 2016 dikeluarkan dimaksudkan dan diharapkan untuk mengurangi terjadinya penumpukan kasus dan penunggakan perkara di Pengadilan serta untuk dapat memenuhi rasa keadilan dengan proses cepat, sederhana dan murah dalam berperkara. Namum kenyataan dari beberapa hasil penelitian(15) diberbagai daerah dan di propinsi Jambi hingga saat ini belum banyak berhasil menyelesaikan sengketa dengan cara mediasi.

${ }^{1}$ Lihat pasal 1851 Kitab Undang-Undang Hukum Perdata

${ }^{2}$ R. Susilo, RIB/HIR dengan Penjelasan, Politea, Bogor, 1985, hlm. 88

${ }^{3}$ M.Yahya Harahap, Hukum Acara Perdata, Sinar Grafika, Jakarta, 2005, hlm. 239

${ }^{4}$ M.Yahya Harahap, Hukum Acara Perdata. 2005, hlm. 241

${ }^{5}$ Yahya Harahap,Hukum Acara Perdata, Sinar Grafika, hlm. 241

${ }^{6}$ Takdir Rahmadi, Mediasi Penyelesaian Sengketa Melalui Pendekatan Mufakat, PT. Raja Grafindo Persada, Jakarta, 2011, hlm.68

${ }^{7}$ Takdir Rahmadi, Mediasi Penyelesaian Sengketa Melalui Pendekatan Mufakat, PT. Raja Grafindo Persada, Jakarta, 2011, hlm.68

${ }^{8}$ Bahder Johan Nasution, Metode Penelitian Hukum, Mandar Maju, Bandung, 2008, hlm.83

${ }^{9}$ Syahrizal Abbas, Mediasi,Jakarta:Kencana Prenada Media Group, 2009, hlm.1-2

${ }^{10}$ Rachmadi Usman, Pilihan Penyelesaian Sengketa di Luar Pengadilan, Bandung, PT. Citra AdityaBakti, 2003,hlm 79

${ }^{11}$ Soesilo Prajogo, KamusHukum Internasional dan Indonesia, Jakarta: Wacana Intelektual,2007, hlm. 52

${ }^{12}$ Takdir Rahmadi, Mediasi Penyelesaian Sengketa Melalui Pendekatan Mufakat, PT. Raja Grafindo Persada, Jakarta, 2011, hlm.68 
${ }^{13}$ Golbert,F.Sander, and N.H.Rogers. Dispute Regulation: Negotiation, Mediation, and Ather Process, Boston Toronto, Little Brown and Company, 1992, hlm. 8

${ }^{14}$ Lihat Pasal 2 ayat 3 PERMA No. 1 Tahun 2008

${ }^{15}$ Lihat Pasal 2 ayat 4 PERMA No. 1 Tahun 2008

${ }^{16}$ Lihat Pasal 17 Ayat (6),(7),dan (9) Perma No. 1 Tahun 2008 